\title{
Scrutinizing the potential use of Discord application as a digital platform amidst emergency remote learning
}

\author{
Endang Wahyuningsih ${ }^{*}{ }^{*}$ https://orcid.org/0000-0002-4837-8614 \\ Baidi $^{2}$ (1) https://orcid.org/0000-0003-3886-0818 \\ ${ }^{1}$ Islamic Education, Sekolah Dasar Negeri 2 Pundungsari Klaten, Indonesia \\ 2Islamic Education Management, Postgraduate IAIN Surakarta, Indonesia
}

\begin{abstract}
A common challenge encountered by educators to engage in an emergency remote learning is the selection of an effective digital platform to assist teaching and learning activities. Drawing on this issue, this study offers a practical solution by scrutinizing the potential use of android-based application named Discord as a digital platform to conduct online teaching and learning. To this end, a group of elementary school teachers and students enrolled in Islamic religious and moral education courses was involved as participants in a descriptive qualitative research by employing interview, observation, and documentation as instruments to collect the required data. The results demonstrated that Discord androidbased application was proven to be an alternative for elementary school educators as a digital learning platform during the emergency remote learning in the age of Covid-19 pandemic. The results of observation further showed that online teaching-learning activities using Discord application could successfully create communicative digital learning environment which was interesting and enjoyable for the students. Despite the potential advantages, a number of challenges were also discussed in this study. The results of this study contribute as a practical insight for teachers and students in assisting online learning activities as Discord application helps them experience a new nuance of distance learning.
\end{abstract}

\author{
ARTICLE INFO \\ Keywords: \\ digital learning platform; \\ Discord application; \\ emergency remote learning; \\ online learning
}

\section{Article History:}

Received: 26 February 2021

Revised: 30 March 2021

Accepted: 31 March 2021

Published: 05 April 2021

\section{How to Cite in APA Style:}

Wahyuningsih, E. \& Baidi.

(2021). Scrutinizing the

potential use of Discord

application as a digital

platform amidst emergency

remote learning. Journal of

Educational Management

and Instruction, 1(1), 9-18.

\section{Introduction}

In the beginning of 2020 on March, people around the world had been shocked after World Health Organization (WHO), on behalf of the United Nations, announced the existence of Novel Coronavirus (2019-nCOV) along with the procedures to avoid its infection (Bainus \& Budi Rahcman, 2020). The government of all countries affected by this contagious disease call upon their society to do social and physical distancing as a practical step to keep away from the virus. Social and physical distancing are behavioral control performed to stop the virus transmission by minimizing the rates of contacts among people (Reluga, 2010). In March 2, 2020, Indonesian government formally informed that Coronavirus disease (Covid-19) has been exist and infected people, although some experts in epidemiology from the University of Indonesia claimed that the virus has been in Indonesia since January 2020 (Pranita et al., 2020).

As the consequences of social and physical distancing, Indonesian government implements particular policy to avoid the massive spread of Covid-19 to the society. Most of people activities are shifted from face-to-face interaction to online-based activities using digital technology such as Work from Home (WFH), online services, rapid-test policy, etc. (Chick et al., 2020; Nugroho \& Atmojo, 2020). People are required to practice healthy procedures when they have to do activities outside their houses by wearing 
mask, maintaining the distance with others, and using hand sanitizer that later this habits is called as new normal life (Bonacini et al., 2021; Septiani, 2020). By the policy, many sectors have been affected and should adapt to the era of new normal, including in education sector.

Through the decree of the minister of Education and Culture number 4 year 2020 that has been emphasized by the circular letter of the general secretary number 15 year 2020 , the educational practices have been decided to be conducted online from teachers' and students' own houses. The learning from home policy was chosen as an effort to put an end to the massive spread of Covid-19 disease and avoid infection among people (Aliyyah et al., 2020; Fauzi \& Khusuma, 2020). Online learning from home also become a consistent commitment of the government to fulfill the educational right of its citizen even though in an emergency condition (Abidah et al., 2020; Putri et al., 2020). Emergency remote learning is also to ensure the psycho-social support for teachers, students, and parents (Kementrian Pendidikan dan Kebudayaan, 2020; Nartiningrum \& Nugroho, 2020).

The emergency remote learning activities are flexible depending on the characteristics of each region. The method and model of learning from home are implemented based on teachers' and students' interests and abilities, so that every region may have different styles of beyond-classroom learning. The focus of teaching and learning from home especially for elementary students is how to keep the students' learning motivation and awareness (Wajdi et al., 2020). By this design, teachers are urged to provide qualitative evaluation instead of quantitative scores to the students, and to keep interaction and communication with the parents whose role is crucial for students' development during emergency remote learning (Fauzi \& Khusuma, 2020). In the context of elementary education, studies have showed that communication and interaction between teachers and students became the primary challenges of conducting School from Home program during Covid-19 pandemic (Aliyyah et al., 2020; Lestari \& Gunawan, 2020). Precedent studies have also highlighted the digital technology readiness to determine the success of online learning in elementary school in the age of emergency remote learning (Rahiem, 2020). Hence, the implementation of distance learning should fully be supported by national curriculum, government, school authorities, and other stakeholders (Baidi et al., 2020; Nugroho \& Mutiaraningrum, 2020; Wajdi et al., 2020).

Previous research has further revealed that distance learning is considered as the most appropriate way of teaching in response to the global pandemic of Covid-19 (Chick et al., 2020; Putri et al., 2020). In the case of Klaten region Central Java Indonesia, the distance learning is conducted in the forms of online learning (daring - dalam jaringan) and offline learning (luring - luar jaringan). Online learning is carried out by the assistance of digital technology and internet sources, while the offline learning is administered by the arrival of teachers in students' houses or often called as a home visit (Direktorat Sekolah Dasar, Direktorat Jendral PAUD, Dikdas dan Dismen, 2020). Addressing this issue, this study focuses on the nature and characteristics of online learning using digital technology instead of offline learning in the form of teachers' arrival and home visit.

Studies on emergency remote learning during the Covid-19 pandemic have depicted that digital platforms such as Google classroom and Learning Management System (LMS) along with social media WhatsApp and Video conferences have been widely used by educators to conduct online learning during the pandemic of Covid-19 (Absor, 2020; Hidayat et al., 2019; Rohidin et al., 2015). However, there has been a few researchers in the area of digital learning have acknowledged the potential use of Discord android-based application to conduct online teaching and learning amidst the emergency remote learning. Discord application is basically an android-based application frequently used as a means of communication among gamers (Raihan. \& 
Putri, 2018; Rakhmawan et al., 2020). Discord is a chat app, similar to programs like Skype or communications platforms like Slack. It supports voice and text chat, video calls, and screen-sharing, giving users multiple options to connect and communicate. It operates on two levels: servers and channels. The server acts as a classroom and the channels set the stage for open discussion. Though it gained popularity as an app for gamers, Discord has diversified its identity and services to cater to communication needs in general (Liu et al., 2014).

Studies on the use of Discord application have resulted in a conclusion that it is convenient for both teachers and students and became an alternative media to optimize online learning activities (Efriani, et al., 2020; Kim \& Smith, 2017; Ramadhan, 2021). A study conducted by Wulanjani (2018) also revealed that Discord application could be an effective digital tool to improve students' communicative abilities such as listening and speaking. It was further found that online learning using Discord application could be a promising way of conducting learning activities besides the use of Google classroom, LMS, social media, and video conference (Kruglyk et al., 2020). In addition, Discord application can also be combined with other learning media that makes this application flexible and friendly users (Ramadhan, 2021). In short, previous studies have acknowledged that Discord application offers a range of potential advantages to be used as a digital tool in educational setting (Efriani, 2020; Wulanjani, 2018).

Having explored the use of digital technology and Discord application to assist online teaching and learning in educational context, a research gap is observable. To the best of the authors' knowledge, there has been no research examining the potential use of Discord application in the context of elementary school education, particularly during the emergency remote learning. Therefore, this study aims to scrutinize the potential use of Discord application as an online platform to assist elementary level teaching and learning in the emergency remote learning during Covid-19 pandemic. This study involved a group of elementary school teachers and students at Klaten region Central Java province Indonesia. The results of this study contribute to providing valuable insights and references for educators about the use of Discord application to assist online teaching and create an interactive digital learning environment.

\section{Method}

\section{Research context and participants}

This study was directed to shed some light on the use of Discord application to assist online teaching and learning in elementary school level during the Covid-19 pandemic. To reach the objective, a descriptive qualitative research using observation, interviews, and documentation (Jhon W. Creswell, 2017; Sudaryono, 2019; Sugiyono, 2019) was employed by involving a group of elementary school teachers and students in Klaten region Central Java province Indonesia as the participants. They were using Discord application as a digital learning platform when Covid-19 pandemic occurred and face-to-face classroom learning should be shifted to online learning. A total of 2 teachers (namely T1 and T2) and 32 students in grade 5 enrolled in Islamic religious and moral education courses were recruited for this study. As in a qualitative research, one of the researchers (the first author) was one of the participants and played role as the key instrument of research (Yin, 2015).

\section{Instruments and data collection}

This study employed interviews, observation, and documentation as the instruments to obtain the required data on the use of Discord application in digital elementary school environment. The interviews were conducted to the two teachers and five students (namely S1-S5) whilst and after they experienced online learning using Discord application. The interviews were conducted in Indonesian as the participants' native language. The online teaching and learning activities using Discord application 
were administered for six meetings in Islamic religious and moral education courses. During these meeting, the researcher, who also acted as the teacher, did observation so that she was be able to describe the procedures of conducting online teaching and learning activities using Discord application. Furthermore, a documentation on the students' progress and performances was also carried out by the researcher to depict the participants' improvement and performances during online teaching and learning process during the School from Home in the age of Covid-19 pandemic.

\section{Data analysis}

The data obtained from interviews, observation, and documentation were analyzed using the procedures of qualitative data analysis according to (Yin, 2015), i.e. data tabulation and coding, data reduction, data presentation, and conclusion drawing. First, the researchers tabulated and coded the participants' responses to see the emerging themes with regards to the concerns of this study on the use of Discord application in digital elementary school environment, its potential advantages, as well as the challenges. Second, the researchers reviewed and omitted the redundant data to ensure that the data were focused and in line with the purpose of this study. Third, the data were presented according to the points of this study and later used as the basis of conclusion drawing. Lastly, the final conclusion was drawn as the results of this study.

\section{Results}

This section presents the results of data analysis obtained from interviews, observation, and documentation. The presentation of the results is divided into two primary themes, i.e. the use of Discord application and its potential advantages in digital environment as well as its challenges for elementary school level. The participants' utterances were also quoted to confirm the description of the findings. The researchers translated their responses without altering the substance.

\section{The use of Discord application and its potential advantages in digital elementary school environment}

The results of interviews with the teachers revealed that Discord application could combine several features such as uploading learning videos, attendance, exercise, and live presentations via mobile phone or laptop as described in Figure 1. Discord application could also be used as a medium of communication and sharing between educators and students. Hence, the emotional relationship between educators and students is maintained even though they cannot meet each other in person. From the observation, it was also depicted that with the Discord application, educators could easily control whether the student was following distance learning or just turning on the application and then abandon his online course. During the observation, it could be seen whether the voice channel of each student is turned on as described in Figure 2. Figure 1 and figure 2 showed that the author had practiced using the Discord application during the online teaching and learning activities. The teaching method conducted was through a presentation in a synchronous learning. Thus, there was a more friendly manner in communication. Hence, when there are obstacles in teaching and learning, the teachers could quickly respond to them. Through interviews, the teachers said that:

"In my opinion, using Discord application is convenient and relatively comfortable for online learning with my students. We can upload learning videos, checking students' attendance list, and doing live presentation. Discord can be used by using mobile phone, laptops, or personal computer" (T1)

"The most interactive thing from Discord application is that it helps me to communicate and share with my students in a more unusual and interesting way" (T2) 


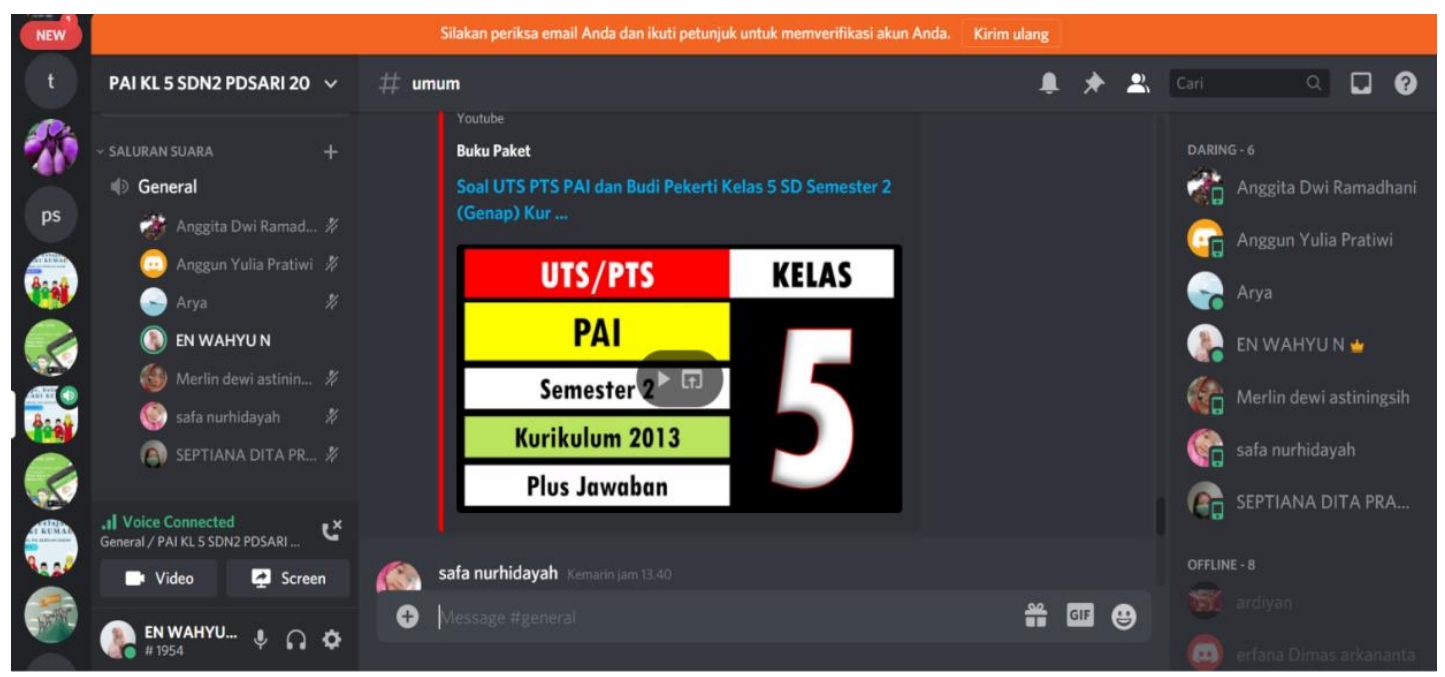

Figure 1. The Teacher Uploaded a Learning Video to the Online Group

The scheme of communication and interaction conducted by researchers in teaching and learning process through the Discord applications was as a teacher and as an observer at the same time. Thus, the researchers are likened to the driving motor of communication among group members by providing clear rules for discussions to run smoothly. For students who will ask questions or interrupt the conversation, they must first turn on the mute button (see mic icon in Figure 1 and Figure 2). That way, the sound can be heard by other participants while others turn off the mute button so that the sound does not interfere with the voice channel.

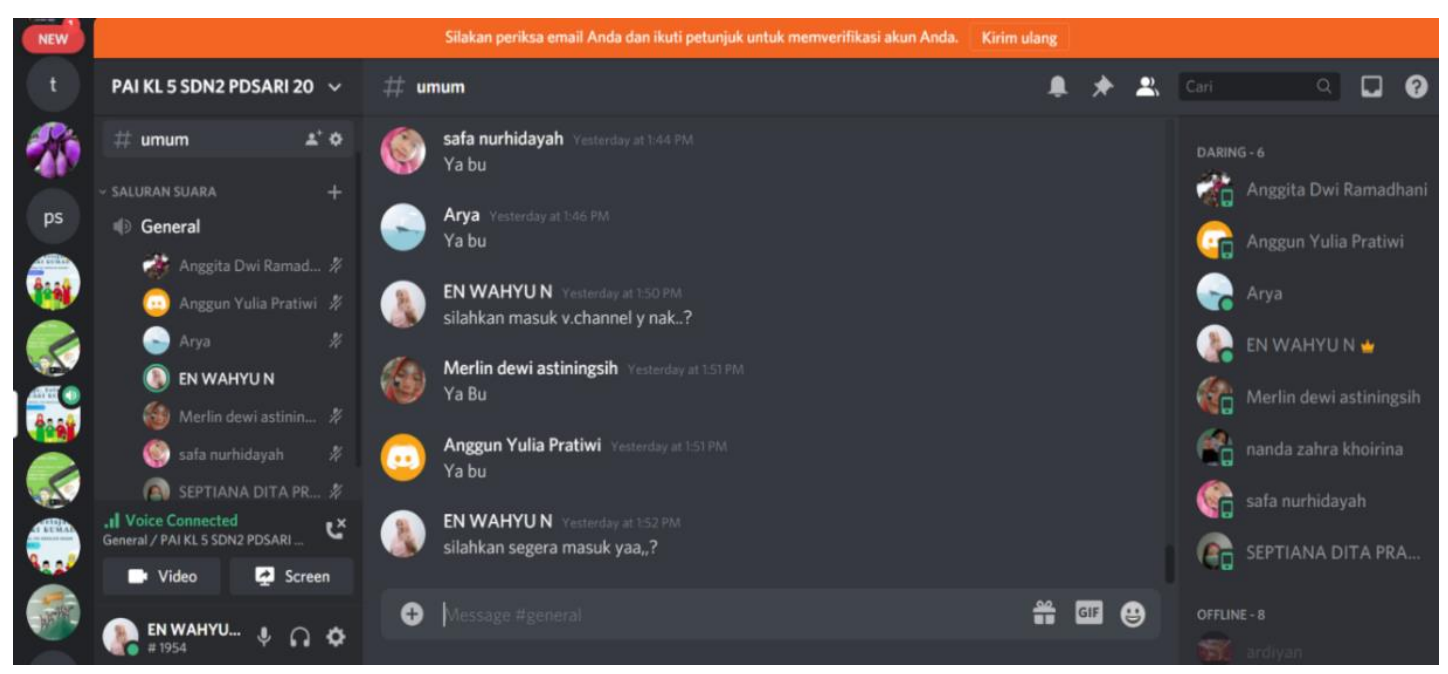

Figure 2. List of Students who attended the Class through the Voice Channel

When it came to the students' perspectives about the use Discord in online teaching and learning, they mentioned that the Discord application could also be utilized by teachers and students to interact outside the class schedule for sharing information, messages, and other credential activities. Moreover, they also confessed that online learning using Discord application was enjoyable and interactive. Some students said that Discord application was similar to WhatsApp, the most frequently used social media in Indonesia. However, they further clarified that its features are more complete than WhatsApp when it is used for online learning media. As several students said in the interviews: 
"In my opinion, this application [Discord] seems to WhatsApp. It enables us to contact and share something, including teaching-learning materials, from teachers to students and vice versa" (S3)

"It [Discord application] is interesting and interactive, even more than WhatsApp. Because I like games, I really enjoy using it" (S1)

"It has more complete features than WhatsApp. That is why, I like it very much when my teacher teaches me how to use it" (S4)

\section{Potential challenges of using Discord application}

Results of the data analysis about the potential challenges of using Discord application for elementary school context were presented in this section. According to the participants, both teachers and students were not familiar with Discord application in the beginning of the online learning. This unfamiliarity resulted in teachers' and students' hesitations to carry out learning activities using this application. However, the results of interviewed in the end of the lesson showed that both teachers' and students' familiarity to Discord application was proven to be improved. Moreover, internet connection also became a particular challenge especially for the students who lived in a village area. Another problem was the fact that a number of students did not have their own digital devices (e.g. mobile phones, tablets, or laptops) so they have to share with their parents or their siblings. As some of the participants said:

"Firstly, I do not know about Discord application until my teacher introduces it to me. I am not really interested in this application because I do not know it before. But, later on I enjoy in using it" (S2)

"The primary problem in using this application is related to internet connection. Discord needs a strong connection, but my students mostly are not acquired with sufficient internet connection since they are living in a village. Also, there are a number of students who do not have their own devices [e.g. mobile phones or laptops] so that they have to share with their parents or their siblings" (T1)

"I do not have my own smartphone so I must join my mother or my brother. I think that is my primary problem" (S3)

".... and about the problem, I think the unfamiliarity with this application at the beginning of the lesson seems to be a problem for us in conducting the online learning using Discord" (T2)

\section{Discussion}

The Covid-19 pandemic struck Indonesia when the Industrial Revolution 4.0 had just been recognized. The demands of all digital shifted people to the digital life since the way people run the work is no longer like before (Dewantara et al., 2020). This also applied to an education domain that educators were forced to utilize technology as a medium of distance teaching (Herliandry et al., 2020; Nugroho \& Fitriati, 2021). From higher education to elementary schools implemented government policies of working from home by learning with technology. It requires harmony among human resources, stakeholder policy, and technology to foster education during pandemic (Amiryousefi, 2019; Ansori \& Sari, 2020; Mutiaraningrum \& Nugroho, 2021).

When it comes to the results of this study, the School from Home program in elementary school level seems to be successfully conducted by utilizing Discord application, despite a range of challenges and difficulties described in this study. This result confirms the previous studies conducted by Wulanjani (2018), Efriani et al. (2020), and Kim and Smith (2017) that Discord application could be used as a digital learning tool in various context of educational environments starting from elementary to higher levels. This study further suggests that bridging Discord application as a new 
digital platform in education environment is challenging but advantageous especially for the students.

Initially, Discord application is a gaming application used by gamers communicate with each other in a large online group (Wulanjani, 2018). As the results of this study showed positive perceptions of the students toward the use of Discord application, it is indicated that their nature of being in love with online games can be optimized to enhance the efficacy of online learning through this platform. Hence, educators must see this phenomena as a potential advantage instead of a difficulty. In addition, it is also found that Discord application can facilitate the communication among teachers and students in a more interactive way and create a new nuance of online learning environment (Houston \& Buzzanell, 2020). Despite some emerging challenges, it is a worth saying that Discord application is a new alternative of digital platform to conduct online learning activities in addition to several existing platforms such as Social media, LMS, and video conferences (Efriani et al., 2020).

In addition to being used for online learning media, the Discord application can also be utilized by teachers and students to interact outside the class schedule for sharing information, messages, and other credential activities. Exchange of communication in the Discord application can be done in four ways: (1) chat on lobby chat menu of text channel or written text channel; (2) voice such as a live or group communication through a voice channel in which only those who join the voice channel can follow the voice despite being a part of the group; (3) combined communication such as communication by combining a text channel and a voice channel in 1 step so that members can have live voice channel and message at text channel at the same time.; (4) private communication such as private communication from group members that allow a secured communication between 2 groups. It proves that technology is an integrated architecture and media set (Casquero et al., 2010; Kumar Basak et al., 2018).

As a final remark of the discussion, the researchers emphasize the contribution and implications of this study's results to the field of teaching and education, particularly at elementary school level. First, since Discord application serves digital media content, it undeniably provides numerous advantages if it is used appropriately to support the efficacy of classroom learning activities. Due to its gaming nature, it gives ample opportunities for young students, who are called as 'digital native', to synchronize their interests and learning enhancements. Second, Discord application allows students to foster autonomous learning since they have full chances to practice and look at learning materials anytime and anywhere without time and space limitations. The primary challenge they have to deal with is ensuring stable internet connection and availability of digital devices (e.g. mobile phones, laptops, tablets, or computers).

\section{Conclusion}

The in-hand study aims to scrutinize the potential use of Discord application as a digital platform to support the efficacy of online learning activities at elementary school level. The results depict that Discord application have successfully assisted emergency remote learning at elementary school level during the Covid-19 pandemic. It is also found that Discord application offers some potential advantages as a digital learning tool. Apart from the advantages, several challenges such as unstable internet connection, unfamiliarity of the application, and availability of digital devices are encountered by the participants. However, the results further show that the participants are successful to deal with these challenges in the end of the learning administration. This study's results contribute to providing a portrait for elementary school educators about the potential use of Discord application. Despite the compelling results, this study acknowledges that this research is conducted at a very descriptive level. Therefore, further studies are recommended to conduct an in-depth inquiry to examine the effectiveness and satisfaction of using Discord application as a digital learning tool. As the final conclusion, 
the researchers with a high pleasure argue that elementary School educators should not hesitate to try using Discord application as one of the digital tools of online learning activities.

\section{Acknowledgements}

Gratitude and acknowledgement go to all participants and the school institution of this study for the support to conduct this research.

\section{References}

Abidah, A., Hidaayatullaah, H. N., Simamora, R. M., Fehabutar, D., \& Mutakinati, L. (2020). The impact of COVID-19 to Indonesian Education and its Relation to the philosophy of "Merdeka Belajar". Studies in Philosophy of Science and Education, $1(1), 38-49$.

Absor, N. F. (2020). Pembelajaran Sejarah Abad 21 : Tantangan dan Peluang dalam Menghadapi Pandemi Covid-19. Journal of History Education, 2(1), 30-35.

Aliyyah, R. R., Rachmadtullah, R., Samsudin, A., Syaodih, E., Nurtanto, M., \& Tambunan, A. R. S. (2020). The perceptions of primary school teachers of online learning during the COVID-19 pandemic period: A case study in Indonesia. Journal of Ethnic and Cultural Studies, 7(2), 90-109.

Amiryousefi, M. (2019). The incorporation of flipped learning into conventional classes to enhance EFL learners' L2 speaking, L2 listening, and engagement. Innovation in Language Learning and Teaching, 13(2), 147-161. https://doi.org/10.1080/17501229.2017.1394307

Ansori, A., \& Sari, A. F. (2020). Inovasi Pendidikan di Masa Pandemi Covid-19. Jurnal Literasi Pendidikan Nusantara, 1(2), 133-148.

Baidi, B., Ramadhan Putra P, H., \& Junaidah, J. (2020). The Effect of Leadership Style and Work Motivation on Work Productivity for Teachers in All State Junior High Schools of Surakarta. Universal Journal of Educational Research, 8(3D), 67-72. DOI: 10.13189/ujer.2020.081710

Bainus, A., \& Budi Rahcman, J. (2020). Editorial: Pandemi Penyakit Menular (Covid-19) Hubungan Internasional. Intermestic: Journal of International Studies, 4(2), 1-11. https://doi.org/10.24198/intermestic.v4n2.1

Bonacini, L., Gallo, G., \& Scicchitano, S. (2021). Working from home and income inequality: risks of a 'new normal'with COVID-19. Journal of population economics, 34(1), 303-360.

Casquero, O., Portillo, J., Ovelar, R., Benito, M., \& Romo, J. (2010). iPLE Network: An integrated elearning 2.0 architecture from a university's perspective. Interactive Learning Environments, 18(3), 293-308. https://doi.org/10.1080/10494820.2010.500553

Chick, R. C., Clifton, G. T., Peace, K. M., Propper, B. W., Hale, D. F., Alseidi, A. A., \& Vreeland, T. J. (2020). Using technology to maintain the education of residents during the COVID-19 pandemic. Journal of surgical education, 77(4), 729-732.

Dewantara, J. A., Efriani, Sulistyarini, \& Prasetiyo, W. H. (2020). Optimization of Character Education Through Community Participation Around The School Environment ( Case Study in Lab School Junior High School Bandung ). Jurnal Etika Demokrasi, 5(1), 53-66.

Direktorat Sekolah Dasar, Direktorat Jendral PAUD, Dikdas dan Dismen, K. P. dan K. (2020). Strategi Pembelajaran jarak Jauh. http://ditpsd.kemdikbud.go.id/artikel/detail/strategi-pembelajaran-jarak-jauh

Efriani, E., Dewantara, J. A., \& Afandi, A. (2020). Pemanfaatan Aplikasi Discord Sebagai Media Pembelajaran Online. Jurnal teknologi informasi dan pendidikan, 13(1), 6165.

Fauzi, I., \& Khusuma, I. H. S. (2020). Teachers' elementary school in online learning of COVID-19 pandemic conditions. Jurnal Iqra': Kajian Ilmu Pendidikan, 5(1), 58-70. 
Herliandry, L. D., Nurhasanah, Suban, M. E., \& Heru, K. (2020). Transformasi Media Pembelajaran Pada Masa Pandemi Covid-19. Jurnal Teknologi Pendidikan, 22(1), 65-70. http://journal.unj.ac.id/unj/index.php/jtp

Hidayat, M. L., Prasetiyo, W. H., \& Wantoro, J. (2019). Pre-service student teachers' perception of using google classroom in a blended course. Humanities and Social Sciences Reviews, 7(2), 363-368. https://doi.org/10.18510/hssr.2019.7242

Houston, J. B., \& Buzzanell, P. M. (2020). Communication and resilience: introduction to the Journal of Applied Communication Research special issue. Journal of Applied Communication Research, 48(1), 1-4. https://doi.org/10.1080/00909882.2020.1711956

Jhon W. Creswell, J. D. C. (2017). Research Design: Qualitative, Quantitative, and Mixed Methods Approaches. SAGE Publications. https://books.google.co.id/books?id=335ZDwAAQBAJ\&dq=research+design+qua litative+quantitative+and+mixed+methods+approaches\&hl=id\&source=gbs_navl inks_s

Kementerian Pendidikan dan Kebudayaan. (2020). Kemendikbud Terbitkan Pedoman Penyelenggaraan Belajar dari Rumah. May 09, 2020.. https://www.kemdikbud.go.id/main/blog/2020/05/kemendikbud-terbitkanpedoman-penyelenggaraan-belajar-dari-rumah

Kim, Y., \& Smith, D. (2017). Pedagogical and technological augmentation of mobile learning for young children interactive learning environments. Interactive Learning Environments, 25(1), 4-16. https://doi.org/10.1080/10494820.2015.1087411

Kruglyk, V., Bukreiev, D., Chornyi, P., Kupchak, E., \& Sender, A. (2020). Discord platform as an online learning environment for emergencies. Ukrainian Journal of Educational Studies and Information Technology, 8(2), 13-28.

Kumar Basak, S., Wotto, M., \& Bélanger, P. (2018). E-learning, M-learning and D-learning: Conceptual definition and comparative analysis. E-Learning and Digital Media, 15(4), 191-216. https://doi.org/10.1177/2042753018785180

Lestari, P. A. S., \& Gunawan, G. (2020). The Impact of Covid-19 Pandemic on Learning Implementation of Primary and Secondary School Levels. Indonesian Journal of Elementary and Childhood Education, 1(2), 58-63.

Liu, S. Y., Zhang, Y. R., Zhao, L. M., Yang, W. L., \& Fan, H. (2014). General monogamy property of global quantum discord and the application. Annals of Physics, 348, 256-269.

Mutiaraningrum, I., \& Nugroho, A. (2021). Smartphone-based mobile assisted language learning application in higher vocational education in Indonesia. JEES Journal of English Educators Society), 6(1), 26-34. https://doi.org/10.21070/jees.v6i1.793

Nartiningrum, N. \& Nugroho, A. (2020). Online Learning amidst Global Pandemic: EFL Students' Challenges, Suggestions, and Needed Materials. ENGLISH FRANCA: Academic Journal of English Language and Education, 4(2), 115-140.

Nugroho, A. \& Fitriati, R. (2021). Flipped Learning Instruction and Pragmatic Competence: A Case of English for Accounting Students. English Learning Innovation, 2(1), 1-9. https://doi.org/10.22219/englie.v2i1.14646

Nugroho, A., \& Atmojo, A. E. P. (2020). Digital learning of english beyond classroom: EFL learners'perception and teaching activities. JEELS (Journal of English Education and Linguistics Studies), 7(2), 219-243. https://doi.org/ 10.30762/jeels.v7i2.1993

Nugroho, A. \& Mutiaraningrum, I. (2020). EFL teachers' beliefs and practices about digital learning of English. Edulite: Journal of English Education, Literature, and Culture, 5(2), 304-321. https://doi.org/ 10.30659/e.5.2.287-303

Pranita, E., (2020). Diumumkan Awal Maret, Ahli: Virus Corona Masuk Indonesia dari Januari. Harian Kompas, https://www. kompas. com/sains/read/2020/05/11/130600623/ 
Putri, R. S., Purwanto, A., Pramono, R., Asbari, M., Wijayanti, L. M., \& Hyun, C. C. (2020). Impact of the COVID-19 pandemic on online home learning: An explorative study of primary schools in Indonesia. International Journal of Advanced Science and Technology, 29(5), 4809-4818.

Raihan, J. P., \& Putri, Y. R. (2018). Pola Komunikasi Group Discord PUBG. INDO. FUN Melalui Aplikasi Discord. eProceedings of Management, 5(3).

Ramadhan, A. (2021). Student's Response Toward Utilizing Discord Application as an Online Learning Media in Learning Speaking at Senior High School. ISLLAC: Journal of Intensive Studies on Language, Literature, Art, and Culture, 5(1), 42-47.

Rahiem, M. D. (2020). The emergency remote learning experience of university students in indonesia amidst the COVID-19 crisis. International Journal of Learning, Teaching and Educational Research, 19(6), 1-26.

Reluga, T. C. (2010). Game theory of social distancing in response to an epidemic. PLoS Computational Biology, 6(5).

Rakhmawan, A., Juansah, D. E., Nulhakim, L., \& ... (2020). Analisis Pemanfaatan Aplikasi Discord Dalam Pembelajaran Daring Di Era Pandemi Covid-19. Prosiding Seminar Nasional Pendidikan FKIP Untirta, 3(1), 55-59.

Rohidin, R. Z., Aulia, R. N., \& Fadhil, A. (2015). Model Pembelajaran PAI Berbasis ELearning (Studi Kasus di SMAN 13 Jakarta). Jurnal Studi Al-Qur'an; Membangun Tradisi Berfikir Qur'ani, 11(2), 114-128.

Septiani, M. (2020). Kaleidoskop Kebijakan Layanan Publik Semasa Pandemi Covid-19. July 30, 2020. https://ombudsman.go.id/artikel/r/artikel--kaleidoskopkebijakan-layanan-publik-semasa-pandemi-covid-19

Sudaryono. (2019). Metodologi Penelitian : Kuantitatif, Kualitatif dan Mix Method (2nd ed.). RajaGrafindo persada, Depok.

Sugiyono. (2019). Metode Peneltian Pendidikan (Kuantitatif, Kualitatif, R\&D dan Penelitian Pendidikan. Yogyakarta: Alfabeta, CV.

Wajdi, M. B. N., Kuswandi, I., Al Faruq, U., Zulhijra, Z., Khairudin, K., \& Khoiriyah, K. (2020). Education Policy Overcome Coronavirus, A Study of Indonesians. EDUTEC: Journal of Education And Technology, 3(2), 96-106.

Wulanjani, A. N. (2018). Discord Application:Turning a Voice Chat Application for Gamers into a Virtual Listening Class. 2nd English Language and Literature International Conference (ELLiC), 2, 115-119.

Yin, R. K. (2015). Qualitative research from start to finish. Guilford publications. 